\title{
LATE PRESENTATION AMONG PATIENTS WITH HUMAN IMMUNODEFICIENCY VIRUS INFECTION IN TURKEY
}

\author{
Hayat Kumbasar Karaosmanoğlư1, Bilgül Mete ${ }^{2}$, Alper Gündüz³, Özlem Altuntaş Aydın', Fatma Sargın", \\ Dilek Yıldız Sevgi ${ }^{3}$, Bülent Durdu ${ }^{5}$, Illyas Dökmetaş ${ }^{3}$, Fehmi Tabak ${ }^{2}$ \\ ${ }^{1}$ Department of Infectious Diseases and Clinical Microbiology, Bakırkoy Dr Sadi Konuk Training and Research Hospital, University of Health \\ Sciences, Istanbul, Turkey \\ ${ }^{2}$ Department of Infectious Diseases and Clinical Microbiology, Cerrahpasa Medical Faculty, Istanbul University, Istanbul, Turkey \\ ${ }^{3}$ Department of Infectious Diseases and Clinical Microbiology, Sisli Hamidiye Training and Research Hospital, University of Health Sciences, \\ Istanbul, Turkey \\ ${ }^{4}$ Department of Infectious Diseases and Clinical Microbiology, Göztepe Training and Research Hospital, Medeniyet University, Istanbul, Turkey \\ ${ }^{5}$ Department of Infectious Diseases and Clinical Microbiology, Medical Faculty, Bezmi Alem University, Istanbul, Turkey
}

\section{SUMMARY}

Objective: Late presentation of the patients with human immunodeficiency virus (HIV) infection is associated with less favourable treatment responses, more accelerated clinical progression, and a higher mortality risk. Although HIV prevalence is low in Turkey, it is steadily increasing and the information about late presentation among HIV-positives is limited. We aimed to analyze the status of late presentation among HIV-positive patients in Turkey.

Methods: All newly diagnosed HIV/AIDS patients from 2003 to 2016 were enrolled in this study by five dedicated centres in Istanbul, Turkey. Demographic data, CD4+ counts, and HIV RNA were collected from medical records and were transferred to a HIV database system. Late presentation was defined as presentation for care with a CD4 count $<350 \mathrm{cells} / \mathrm{mm}^{3}$ or presentation with an AIDS-defining event, regardless of the CD4 cell count. A medical literature search was done for the analysis of late presentation in Turkey.

Results: The cohort included 1,673 patients (1,440 males, median age 35 years). Among them, $847(50.6 \%)$ had an early diagnosis, with a CD count of more than $350 \mathrm{cell} / \mathrm{s} / \mathrm{mm}^{3}$. The remaining 826 were late presenters. Among late presenters, 427 ( $25.5 \%$ of all, $51.7 \%$ of late presenters) presented with advanced HIV disease. Late presenters were more elderly and less educated. The gender seemed comparable between groups. Late presentation was more likely among married patients. Early presenters were more likely among homosexuals, those diagnosed in screening studies, and in lower HIV-RNA viral load category. There has been a decreasing trend among late presenters in 2011-2016 when compared to 2003-2011 period.

Conclusion: Current data suggest that half of HIV-infected patients present late in Turkey. In our cohort, those presented late were more elderly, less educated, married and had heterosexual intercourse. On admission, late presenters had more HIV-related diseases and were more likely in higher HIV-RNA category. In the cohort, men having sex with men were less likely late presenters. Efforts to reduce the proportion of late presentation are essential for almost every country. The countries should identify the risk factors of late presentation and should improve early diagnosis and presentation for HIV care.

Key words: late presentation, human immunodeficiency virus infection, acquired immunodeficiency syndrome

Address for correspondence: H. Kumbasar Karaosmanoğlu, Department of Infectious Diseases and Clinical Microbiology, Bakırkoy Dr Sadi Konuk Training and Research Hospital, University of Health Sciences, Bakırkoy Dr. Sadi Konuk EAH, A Blok, Zuhuratbaba, Istanbul, Turkey. E-mail: drhayat1@hotmail.com

https://doi.org/10.21101/cejph.a5416

\section{INTRODUCTION}

Human immunodeficiency virus (HIV) infection is generally diagnosed years after the primary infection (1). It is either diagnosed by HIV-antibody testing in an otherwise healthy person or the patient presents late with an adult immune deficiency syndrome (AIDS) defining illness. There is increasing evidence that early diagnosis and initiation of effective antiretroviral therapy control the HIV-related morbidity and mortality $(2,3)$.
Late presentation is associated with less favourable treatment responses, more accelerated clinical progression, and a higher mortality risk. In addition, late presenters produce a significant burden to the healthcare systems: they may have transmitted the virus to others since they are unlikely to be aware of their infection and they require more healthcare resources than those diagnosed earlier (4).

The recent evidence from the Strategic Timing of Antiretroviral Treatment (START) trial determined when to start antiretroviral 
therapy (ART) in people with asymptomatic HIV infection. In START, HIV-positive individuals with a CD4 count $<500$ cells/ $\mathrm{mm}^{3}$ were randomized to immediate ART initiation or deferral until their CD4 count declined to 350 cells $/ \mathrm{mm}^{3}$. The interim analysis showed that immediate initiation of therapy was associated with a reduction in the incidence of serious AIDS-related, serious non-AIDS-related events and death from any cause compared with deferring ART until the CD4 count declined to less than 350 cells $/ \mathrm{mm}^{3}$. These events decreased by $57 \%$ among those starting ART immediately compared to the deferred ART $\mathrm{arm}$. The overall reduction included a reduction in tuberculosis, lymphoma and Kaposi's sarcoma. Considering the results of the START trial, guidelines of the World Health Organization (WHO), European AIDS Clinical Society (EACS) and British HIV Association (BHIVA) recommended that ART should be initiated in all HIV-positive adults with any CD4 cell count (5-7). Further, randomized clinical trial data were also available from the Temprano trial recruiting 1,600 participants in Ivory Coast, which also demonstrated a reduced risk of death associated with earlier ART initiation (8). However, despite efforts to provide ART to all HIV-positive patients, around one third of the patients with HIV infection continue to present late (9). Late presentation for HIV infection remains an unresolved challenge.

Turkey is among low-prevalence countries in Europe in HIV infection. The information about late presentation among HIVpositives in the country is limited. We aimed to analyze the status of late presentation among HIV-positive patients in Turkey.

\section{MATERIALS AND METHODS}

The HIV-positive patients were enrolled in this study by the Action against HIV in Istanbul (ACTHIV-IST) Study Group, which consists of five dedicated HIV centres in Istanbul, Turkey. Three of these centres are located in university hospitals and two are in public training hospitals. All newly diagnosed HIV/AIDS patients with confirmed diagnosis were tested using Western Blot verification test (HIV BLOT 2.2, MP Biomedicals Asia Pacific, Singapore). The CD4+ cell counts were obtained by standard flow cytometry (FACScalibur, Becton Dickinson, New Jersey, USA) and HIV viral load was measured by PCR (COBAS Ampliprep/ COBAS TaqMan HIV-1 Test, Roche Molecular Systems, USA). Demographic data including age, sex, transmission routes, education level, marital status, and history of imprisonment, CD4+ counts, and HIV RNA were collected from medical records and were transferred to the HIV database system.

Late presentation was defined as presentation for care with a CD4 count below 350 cells $/ \mathrm{mm}^{3}$ or presentation with an AIDSdefining event, regardless of the CD4 cell count.

Presentation with advanced HIV disease was defined as presentation for care with a CD4 count below 200 cells $/ \mathrm{mm}^{3}$ or presentation with an AIDS-defining event, regardless of the CD4 cell count (10).

An analysis of late presentation in Turkey was searched in PubMed (Medline) using the key words of "late presentation", "HIV", and "Turkey". Only recently diagnosed, treatment-naive cohorts were determined. Those describing the patients by CD4 count were included. Meeting presentations were excluded. Additional publications were proposed by the authors.
All analyses were performed using SPSS 15 (SPSS Inc, Chicago, IL, USA). Data were described using mean \pm standard deviation (SD) (or median and range) and as an absolute number and percentage when indicated. The student $t$ test was used to analyze quantitative data. The chi-square test was used to analyze categorical variables. A p value $<0.05$ was considered as statistically significant.

\section{RESULTS}

The cohort included 1,673 patients (1,440 males, median age 35 years). The characteristics of the patients are given in Table 1. Among them, $847(50.6 \%)$ had an early diagnosis, with a CD count of more than 350 cells $/ \mathrm{mm}^{3}$. The remaining 826 were latepresenters (Table 2). Among late presenters, 427 (25.5\% of all, $51.7 \%$ of late presenters) presented with advanced HIV disease. The characteristics of late and non-late, "early" presenters are given in Table 2. Late presenters were more elderly and less educated. The gender seemed comparable between the groups. Late presenters were more likely among married patients. Early presenters were more likely among homosexuals, those diagnosed in screening studies, and in lower HIV-RNA viral load category. There has been a decreasing trend among late presenters in 2011-2016 when compared to 2003-2011 period.

Six previous studies of treatment-naive patients from Turkey reported the patient number by CD4 count (11-16). Four studies (12-15) used the classification of CD4 counts $<200 /$ $\mathrm{mm}^{3}, 200-350 / \mathrm{mm}^{3}, 350-500 / \mathrm{mm}^{3},>500 / \mathrm{mm}^{3}$, one study (11) used $<100 / \mathrm{mm}^{3}, 100-350 / \mathrm{mm}^{3}, 350-500 / \mathrm{mm}^{3},>500 / \mathrm{mm}^{3}$ and another study (16) used $<200 / \mathrm{mm}^{3}, 200-500 / \mathrm{mm}^{3},>500 / \mathrm{mm}^{3}$. The patients by CD4 count in the studies and in the current study are shown in Table 3.

\section{DISCUSSION}

In Turkey, the first case of HIV/AIDS was reported in 1985. According to the survey conducted by the Turkish Ministry of Health, there were 13,181 cases of HIV infection out of a population of 78.9 million people in Turkey between October 1985 and July 2016 (17). Among these patients, the transmission route was unknown in $46 \%$, heterosexual contact in $38 \%$ and homosexual

Table 1. Characteristics of patients included in cohort

\begin{tabular}{|l|c|}
\hline Patient number & 1,673 \\
\hline Sex (male/female) & $1,440 / 233$ \\
\hline \multicolumn{2}{|l|}{ Transmission route } \\
\hline Heterosexual intercourse & 639 \\
\hline Homosexual intercourse & 572 \\
\hline Intravenous drug use & 9 \\
\hline Blood/blood product use & 20 \\
\hline Other & 5 \\
\hline Unknown & 368 \\
\hline Median CD4 cell (count/mm³) & 353 \\
\hline Median HIV RNA level (copies/mL) & 98,150 \\
\hline
\end{tabular}


contact in $13 \%$, and injecting drug use in $2 \%$. In a recent study of 829 untreated HIV-1 positive Turkish patients, the male patients reached $84 \%$ and the probable route of transmission was heterosexual intercourse in $437(53 \%)$ patients and homosexual intercourse in $256(31 \%)$ patients (14). In the largest series $(n=$ 1,292) of HIV-positive patients from Turkey, we reported that there was a male predominance $(85 \%)$ and that men having sex with men (MSM) accounted for $40 \%$ of all patients with available sex preference data (18).
Current data showed that half of HIV-infected patients present late in Turkey. In recently diagnosed patient cohorts, mean (or median in some studies) CD4 counts were reported in a range of 236 to $441 / \mathrm{mm}^{3}$ (Table 4) (19-24). In the first analysis of late presenters in the country, we noted that late presenters corresponded to $66 \%$ of 209 newly diagnosed HIV-positive individuals (13). Among late presenters, $58 \%$ of them (38\% of all) presented with advanced HIV disease. In a recent study of 237 patients, $>500 /$ $\mathrm{mm}^{3}$ was $23 \%, 200-500 / \mathrm{mm}^{3}$ was $37 \%$ and $<200 / \mathrm{mm}^{3}$ was $40 \%$

Table 2. Characteristics of early and late presenters $(N=1,673)$

\begin{tabular}{|c|c|c|c|c|c|}
\hline \multirow[t]{2}{*}{ Characteristics } & \multicolumn{2}{|c|}{$\begin{array}{l}\text { Late presenters } \\
\text { CD4 } \leq 350 / \mathrm{mm}^{3} \\
\quad(\mathrm{n}=826)\end{array}$} & \multicolumn{2}{|c|}{ 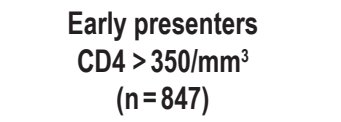 } & \multirow[t]{2}{*}{$\mathrm{p}$-value } \\
\hline & $n$ & $\%$ & $n$ & $\%$ & \\
\hline \multicolumn{6}{|l|}{ Age } \\
\hline$<18$ years & 4 & 0.5 & 9 & 1.1 & \multirow{4}{*}{$<0.001$} \\
\hline $18-35$ years & 369 & 44.7 & 493 & 58.2 & \\
\hline $36-50$ years & 318 & 38.5 & 262 & 30.9 & \\
\hline$>50$ years & 135 & 16.3 & 83 & 9.8 & \\
\hline Sex (male/female) & \multicolumn{2}{|c|}{$698 / 128$} & \multicolumn{2}{|c|}{$742 / 105$} & 0.039 \\
\hline \multicolumn{6}{|l|}{ Marital status* } \\
\hline Married & 321 & 38.9 & 245 & 28.9 & \multirow{3}{*}{$<0.001$} \\
\hline Unmarried & 322 & 39.0 & 436 & 51.5 & \\
\hline Widowed & 69 & 8.4 & 46 & 5.4 & \\
\hline \multicolumn{6}{|l|}{ Education } \\
\hline Illiterate & 273 & 33.1 & 254 & 30.0 & \multirow{6}{*}{0.001} \\
\hline Literate & 5 & 0.6 & 3 & 0.4 & \\
\hline Primary school & 119 & 14.4 & 86 & 10.2 & \\
\hline Secondary school & 83 & 10.0 & 63 & 7.4 & \\
\hline High school & 143 & 17.3 & 155 & 18.3 & \\
\hline University & 199 & 24.1 & 285 & 33.6 & \\
\hline \multicolumn{6}{|l|}{ Risk group* } \\
\hline Heterosexual intercourse & 405 & 49.0 & 234 & 27.6 & \multirow{5}{*}{$<0.001$} \\
\hline Homosexual intercourse & 257 & 31.1 & 315 & 37.2 & \\
\hline Intravenous drug use & 8 & 1.0 & 1 & 0.1 & \\
\hline Blood/blood product use & 5 & 0.6 & 15 & 1.8 & \\
\hline Other & 3 & 0.4 & 2 & 0.2 & \\
\hline \multicolumn{6}{|l|}{ Diagnosis* } \\
\hline Screening tests & 393 & 47.6 & 541 & 63.9 & \multirow{2}{*}{$<0.001$} \\
\hline HIV-related diseases & 330 & 40.0 & 180 & 21.3 & \\
\hline \multicolumn{6}{|l|}{ Years of admission } \\
\hline 1993-2000 & 4 & 0.5 & 1 & 0.1 & \\
\hline 2001-2005 & 21 & 2.5 & 14 & 1.7 & \multirow{3}{*}{$<0.001$} \\
\hline $2006-2010$ & 208 & 25.2 & 136 & 16.1 & \\
\hline 2011-2016 & 593 & 71.8 & 696 & 82.2 & \\
\hline \multicolumn{6}{|l|}{ HIV RNA level category* } \\
\hline$>100,000$ copies $/ \mathrm{mL}$ & 417 & 50.5 & 273 & 32.2 & \multirow{2}{*}{$<0.001$} \\
\hline$\leq 100,000$ copies $/ \mathrm{mL}$ & 289 & 35.0 & 459 & 54.2 & \\
\hline
\end{tabular}

*The total does not reach $100 \%$ because of data in "unknown" category. 
Table 3. CD4 counts and patients by CD4 count among treatment-naive HIV-infected patients from Turkey*

\begin{tabular}{|c|c|c|c|c|c|}
\hline \multirow{2}{*}{ Reference } & \multirow{2}{*}{ Year } & \multirow{2}{*}{ Number of patients } & \multirow{2}{*}{$\begin{array}{c}\text { Mean } / \text { median CD4 } \\
\text { count } / \mathrm{mm}^{3}\end{array}$} & \multicolumn{2}{|c|}{ Patients by CD4 } \\
\hline & & & & count $/ \mathrm{mm}^{3}$ & $\mathrm{n}(\%)$ \\
\hline \multirow{4}{*}{ Aydin et al. (11) } & \multirow{4}{*}{2011} & \multirow{4}{*}{164} & \multirow{4}{*}{ NR } & $>500$ & $27(16.5)$ \\
\hline & & & & $350-500$ & $31(19)$ \\
\hline & & & & $100-350$ & $70(42.5)$ \\
\hline & & & & $<100$ & $36(22)$ \\
\hline \multirow{4}{*}{ Karaosmanoğlu et al. (12) } & \multirow{4}{*}{2011} & \multirow{4}{*}{136} & \multirow{4}{*}{$\begin{array}{l}\text { Median (range): } \\
302(9-1,270)\end{array}$} & $>500$ & $20(15)$ \\
\hline & & & & $350-500$ & $22(16)$ \\
\hline & & & & $200-350$ & $41(30)$ \\
\hline & & & & $<200$ & $53(39)$ \\
\hline \multirow{3}{*}{ Karaosmanoğlu et al. (13) } & \multirow{3}{*}{2013} & \multirow{3}{*}{209} & \multirow{3}{*}{ NR } & $>350$ & $72(34)$ \\
\hline & & & & $200-350$ & $58(28)$ \\
\hline & & & & $<200$ & $79(38)$ \\
\hline \multirow{3}{*}{ Yemisen et al. (14) } & \multirow{3}{*}{2014} & \multirow{3}{*}{788} & \multirow{3}{*}{ Mean \pm SD: $358 \pm 271$} & $>350$ & $347(44)$ \\
\hline & & & & $200-350$ & $189(24)$ \\
\hline & & & & $<200$ & $252(32)$ \\
\hline \multirow{4}{*}{ Aydin et al. (15) } & \multirow{4}{*}{2015} & \multirow{4}{*}{306} & \multirow{4}{*}{$\begin{array}{l}\text { Mean (range): } \\
394(4-1,270)\end{array}$} & $>500$ & $67(22)$ \\
\hline & & & & $350-500$ & $56(18)$ \\
\hline & & & & $200-350$ & $82(27)$ \\
\hline & & & & $<200$ & $101(33)$ \\
\hline \multirow{3}{*}{ Çerçi et al. (16) } & \multirow{3}{*}{2016} & \multirow{3}{*}{237} & \multirow{3}{*}{$\begin{array}{c}\text { Mean: } 260 \text { (240 before } \\
\text { 2006; } 375 \text { after 2006) }\end{array}$} & $>500$ & $54(23)$ \\
\hline & & & & $200-500$ & $88(37)$ \\
\hline & & & & $<200$ & $95(40)$ \\
\hline \multirow{3}{*}{ Current study } & \multirow{3}{*}{2017} & \multirow{3}{*}{1,673} & \multirow{3}{*}{ Median: 353} & $>350$ & $847(50.5)$ \\
\hline & & & & $200-350$ & $399(24)$ \\
\hline & & & & $<200$ & $427(25.5)$ \\
\hline
\end{tabular}

${ }^{*}$ The patients may overlap in the cohorts.

NR - not reported

Table 4. CD4 counts of treatment-naive HIV-infected patients from Turkey*

\begin{tabular}{|l|c|c|c|}
\hline Reference & Year & Number of patients & $\begin{array}{c}\text { CD4 } \\
\text { count/mm }\end{array}$ \\
\hline Aydin et al. (19) & 2013 & 120 & Mean \pm SD: $441 \pm 216$ \\
\hline Sayan et al. (20) & 2013 & 394 & Median (range): 340 (1-1,660) \\
\hline Yalçınkaya et al. (21) & 2014 & 190 & Median (range): 280 (0-1,000) \\
\hline Aydin et al. (22) & 2015 & 308 & TPHA(-) group, mean \pm SD: $336 \pm 16$ \\
\hline Sayan et al. (23) & 2016 & 1306 & Median (range): 361 (4-1,351) \\
\hline Sayan et al. (24) & 2016 & 78 & Median (range): 236 (6-626) \\
\hline
\end{tabular}

SD - standard deviation, TPHA - Treponema pallidum hemagglutination

${ }^{*}$ The patients may overlap in the cohorts.

(16). The other studies reported the rate of patients presented with $<350 / \mathrm{mm}^{3}$ as $56 \%$ to $69 \%(11-15)$. Those with a CD4 of $<200 /$ $\mathrm{mm} 3$ were available in 5 studies and it ranged from $32 \%$ to $40 \%$ (12-16). In the current study, which represents the largest HIVpositive population reported from the country, half of the patients were late presenters and a quarter of the patients presented with advanced HIV disease.
The definition of late presentation is debateful and more than 20 different definition were cited in the literature (4, 9, 10, 25-31). Although the most common definitions have been based on CD4 count, there has been no consistency among definitions, making the estimate of epidemiology of late presentation more challenging. Definitions based on the presence of AIDS at diagnosis or on very low CD4 cell counts $\left(<50 / \mathrm{mm}^{3}\right.$ for example) estimates 
$10-15 \%(26,27)$, whereas definitions based on higher CD4 counts $\left(<200-350 / \mathrm{mm}^{3}\right)$ report $30-40 \%(28-31)$. The Late Presentation for HIV Treatment in Europe programme was initiated in 2008. In 2011, the initiative released a consensus definition to identify the persons at particularly increased risk of disease progression and provide improvement in surveillance and public health needs (10). Two definitions were agreed: late presentation (CD4 count $<350 / \mathrm{mm}^{3}$, or presentation with an AIDS defining event regardless of CD4 count) and presentation with advanced HIV disease (CD4 count $<350 / \mathrm{mm}^{3}$, or presentation with an AIDS defining event regardless of CD4 count).

In our cohort, those presented late were more elderly, less educated, married and had heterosexual intercourse. On admission, late presenters had more HIV-related diseases and were more likely to be in higher HIV-RNA category. In the cohort, relatively less MSM patients were diagnosed as late presenters. (257/826, $31 \%$ vs. $315 / 847,37 \%$ ). This finding was in accordance with other cohorts $(29,32)$ and can be explained by increased awareness of HIV infection among MSM compared with heterosexuals. A higher proportion of MSM are tested for HIV suggesting a selection bias towards MSM and HIV tests either on routine screening or during the course of acute infection.

The Collaboration of Observational HIV Epidemiological Research Europe (COHERE) study including 30,454 patients from 34 countries reported that the median CD4 count at presentation was $368 / \mathrm{mm}^{3}$ (33). In $2010,47.5 \%$ of the patients had CD4 $<350 / \mathrm{mm}^{3}$, while this figure was $48.7 \%$ in 2013 . There was significant increase in male and female patients who inject drugs and a significant decline in late presenters in northern Europe. Across Europe, certain groups carry increased risk for late presentation including intravenous drug use, older age, foreign birth, and non-White ethnicity (34). Beside this big scale cohort across Europe, several European countries reported their cohorts determining the status of late presentation and the factors determining it. In Swiss HIV cohort study including 1,366 patients late presenters were more likely to be females or from sub-Saharan Africa and less likely to be highly educated or MSM (32). Among the 20,496 patients, 53.9\% presented late and $31.2 \%$ had advanced HIV disease (including 2,253 patients with AIDS) in a big scale French cohort (35). MSMs were less likely than all other transmission groups to present late, and the risk of late presenters increased with age. The frequency of late presenter decreased from $57.1 \%$ among patients enrolled in 2003-2004 to 49.7\% in 2007-2009 (35). In Danish cohort, 3,027 patients were diagnosed with HIV from $1995-2009 ; 34.7 \%$ had advanced HIV disease and 51.2\% were late presenters. Age > 50 years, heterosexuals of non-Danish origin, 'other' route of transmission, and diagnosis before 2002 were associated with an increased risk of presenting with advanced HIV, whereas a negative HIV test prior to diagnosis was associated with a significantly reduced risk (36).

In an Asian cohort, among 3,744 patients, 2,681 (72\%) were late presenters. Older patients and injecting drug users were more likely to be late presenters. Homosexual HIV exposure and females were less likely to be late presenters (37). In an African cohort of 14,487 eligible patients, $85.6 \%$ were late presenters and $63 \%$ presented with advanced HIV disease. Late presentation decreased from $88.9 \%$ in 2005 to $80.1 \%$ in 2010 and advanced HIV disease from $67.8 \%$ in 2005 to $53.6 \%$ in 2010 .
Male sex, older age and hepatitis B virus and hepatitis $\mathrm{C}$ virus coinfections were associated with late presentation. Male sex, older age, unemployment and hepatitis B virus coinfection were among the predictors of advanced HIV disease (38). In contrast to the recent efforts to determine all HIV-infected patients and to treat them to control the disease burden, many individuals present to the clinical care in an advanced stage.

\section{CONCLUSION}

The late presentation is a challenge for the given patient since it goes with a significantly higher morbidity and mortality. It is also a challenge for the healthcare services. Efforts to reduce the proportion of late presentation are essential for almost every country. The countries should identify the risk factors of their late presenters and should use targeted public health interventions to improve early diagnosis and presentation for HIV care. Improvements in HIV testing policies emphasizing vulnerable groups are crucial.

\section{Conflict of Interests}

None declared

\section{REFERENCES}

1. Pedersen C, Lindhardt BO, Jensen BL, Lauritzen E, Gerstoft J, Dickmeiss $\mathrm{E}$, et al. Clinical course of primary HIV infection: consequences for subsequent course of infection. BMJ. 1989;299(6692):154-7.

2. Jensen-Fangel S, Pedersen L, Pedersen C, Larsen CS, Tauris P, Moller A, et al. Low mortality in HIV-infected patients starting highly active antiretroviral therapy: a comparison with the general population. AIDS. 2004;18(1):89-97.

3. Ormaasen V, Sandvik L, Dudman SG, Bruun JN. HIV related and nonHIV related mortality before and after the introduction of highly active antiretroviral therapy (HAART) in Norway compared to the general population. Scand J Infect Dis. 2007;39(1):51-7.

4. Antinori A, Johnson M, Moreno S, Yazdanpanah Y, Rockstroh JK. Report of a European Working Group on late presentation with HIV infection: recommendations and regional variation. Antivir Ther. 2010;15 Suppl $1: 31-5$.

5. World Health Organization. Guideline on when to start antiretroviraltherapy and on pre-exposure prophylaxis for HIV [Internet]. Geneva: WHO; 2015 [cited 2019 Jun 25]. Available from: http://www.who.int/ hiv/pub/guidelines/earlyrelease-arv/en.

6. European AIDS Clinical Society (EACS). Guidelines [Internet]. 2015 [cited 2019 Jun 25]. Available from: http://www.eacsociety.org/ files/2015_eacsguidelines_8_0-english_rev-20160124.pdf.

7. Waters L, Ahmed N, Angus B, Boffito M, Bower M, Churchill D, et al. BHIVA guidelines for the treatment of HIV-1-positive adults with antiretroviral therapy 2015 [Internet]. BHIVA; 2016 [cited 2019 June 25]. Available from: http://www.bhiva.org/HIV-1-treatment-guidelines. aspx.

8. TEMPRANO ANRS 12136 Study Group. A Trial of early antiretrovirals and isoniazid preventive therapy in Africa. N Engl J Med. 2015;373(9):808-22.

9. D'Arminio Monforte A, Antinori A, Girardi E, Ceccherini-Silberstein F, Marchetti G, Sabin CA, et al. HIV-infected late presenter patients. AIDS Res Treat. 2012;2012:902679. doi: 10.1155/2012/902679.

10. Antinori A, Coenen T, Costagiola D, Dedes N, Ellefson M, Gatell J, et al.; European Late Presenter Consensus Working Group. Late presentation of HIV infection: a consensus definition. HIV Med. 2011;12(1):61-4.

11. Aydın OA, Karaosmanoğlu HK, Korkusuz R, Nazlıcan O. Toxoplasma gondii IgG seroprevalence in HIV/AIDS patients. Turkiye Parazitol Derg. 2011;35(2):65-7. (In Turkish.)

12. Karaosmanoglu HK, Aydin OA, Nazlican O. Profile of HIV/AIDS patients in a tertiary hospital in Istanbul, Turkey. HIV Clin Trials. 2011;12(2):104-8. 
13. Karaosmanoglu HK, Aydin OA, Johansen IS, Korkusuz R, Nazlican O. Late presenters and significance of screening tests in early diagnosis of HIV infection in Istanbul. HealthMED. 2013;7(4):1187-91.

14. Yemisen M, Aydın OA, Gunduz A, Ozgunes N, Mete B, Ceylan B, et al. Epidemiological profile of naive HIV-1/AIDS patients in Istanbul: the largest case series from Turkey. Curr HIV Res. 2014;12(1):60-4.

15. Aydin ÖA, Karaosmanoğlu HK, Korkusuz R, Özeren M, Özcan N. Mucocutaneous manifestations and the relationship to CD4 lymphocyte counts among Turkish HIV/AIDS patients in Istanbul, Turkey. Turk J Med Sci. 2015;45(1):89-92.

16. Çerçi P, İnkaya AÇ, Alp Ş, Tümer A, Ünal S. Evaluation of 255 HIV/AIDS cases: Hacettepe cohort, Ankara, Turkey. Mikrobiyol Bul. 2016;50(1):94103. (In Turkish.)

17. HATAM. HIV/AIDS cases according to the year of distribution [Internet]. Ankara: Ministry of Health of Turkey; 2016 [cited 2019 June 25]. Available from: http://www.hatam.hacettepe.edu.tr/AIDS_web-2016.pdf. (In Turkish.)

18. Sargin F, Yildiz D, Aydin OA, Mete B, Gunduz A, Karaosmanoglu HK, et al. Changes in HIV demographic patterns in a low prevalence population: no evidence of a shift towards men who have sex with men. Int J Infect Dis. 2016;48:52-6.

19. Aydın OA, Karaosmanoglu HK, Karahasanoglu R, Tahmaz M, Nazlican O. Prevalence and risk factors of osteopenia/osteoporosis in Turkish HIV/ AIDS patients. Braz J Infect Dis. 2013;17(6):707-11.

20. Sayan M, Simşek F, Ceran N, Dokuzoğuz B, Eraksoy H. APOBEC3 hypermutations in HIV-1 infected cases in Turkey. Mikrobiyol Bul. 2013;47(3):482-92. (In Turkish.)

21. Yalçınkaya T, Köse S. Investigation of HIV-1 primary drug resistance mutations in antiretroviral therapy-naive cases. Mikrobiyol Bul. 2014;48(4):585-95. (In Turkish.)

22. Aydin ÖA, Karaosmanoğlu HK, Sayan M, İnce ER, Nazlıcan Ö. Seroprevalence and risk factors of syphilis among HIV/AIDS patients in Istanbul, Turkey. Cent Eur J Public Health. 2015;23(1):65-8.

23. Sayan M, Sargin F, Inan D, Sevgi DY, Celikbas AK, Yasar K, et al. HIV-1 transmitted drug resistance mutations in newly diagnosed antiretroviralnaive patients in Turkey. AIDS Res Hum Retroviruses. 2016;32(1):26-31.

24. Sayan M, Gündüz A, Ersöz G, İnan A, Deveci A, Özgür G, et al. Integrase Strand Transfer Inhibitors (INSTIs) resistance mutations in HIV-1 infected Turkish patients. HIV Clin Trials. 2016;17(3):109-13.

25. Kozak M, Zinski A, Leeper C, Willig JH, Mugavero MJ. Late diagnosis, delayed presentation and late presentation in HIV: proposed definitions, methodological considerations and health implications. Antivir Ther. 2013;18(1):17-23.

26. Sabin CA, Smith CJ, Gumley H, Murphy G, Lampe FC, Phillips AN, et al. Late presenters in the era of highly active antiretroviral therapy: uptake of and responses to antiretroviral therapy. AIDS 2004; 18(16):2145-51.
27. Stöhr W, Dunn D, Porter K, Hill T, Gazzard B, Walsh J, et al.; UK CHIC Study. CD4 cell count and initiation of antiretroviral therapy: trends in seven UK centres, 1997-2003. HIV Med. 2007;8(3):135-41.

28. Wolbers M, Bucher HC, Furrer H, Rickenbach M, Cavassini M, Weber R, et al. Delayed diagnosis of HIV infection and late initiation of antiretroviral therapy in the Swiss HIV Cohort Study. HIV Med 2008; 9(6):397-405.

29. Leutscher PD, Laursen T, Andersen B, Ostergaard L, Laursen A, Larsen CS. HIV late presenters in Denmark: need for increased diagnostic awareness among general practitioners. Dan Med Bull. 2011;58(4):A4253.

30. Lanoy E, Mary-Krause M, Tattevin P, Perbost I, Poizot-Martin I, Dupont $\mathrm{C}$, et al. Frequency, determinants and consequences of delayed access to care for HIV infection in France. Antivir Ther. 2007;12(1):89-96.

31. Borghi V, Girardi E, Bellelli S, Angeletti C, Mussini C, Porter K, et al. Late presenters in an HIV surveillance system in Italy during the period 1992-2006. J Acquir Immune Defic Syndr. 2008;49(3):282-6.

32. Hachfeld A, Ledergerber B, Darling K, Weber R, Calmy A, Battegay M, et al.; Swiss HIV Cohort Study. Reasons for late presentation to HIV care in Switzerland. J Int AIDS Soc. 2015 Nov 18;18:20317. doi: 10.7448/ IAS.18.1.20317.

33. The late presenters working group in COHERE in EuroCoord. Late presentation for HIV care across Europe: update from the Collaboration of Observational HIV Epidemiological Research Europe (COHERE) study, 2010 to 2013. Euro Surveill. 2015;20(47). doi: 10.2807/1560-7917. ES.2015.20.47.30070.

34. Johnson M, Sabin C, Girardi E. Definition and epidemiology of late presentation in Europe. Antivir Ther. 2010;15 Supp1 1:3-8.

35. Montlahuc C, Guiguet M, Abgrall S, Daneluzzi V, de Salvador F, Launay O, et al.; French Hospital Database ANRS CO4 cohort. Impact of late presentation on the risk of death among HIV-infected people in France (2003-2009). J Acquir Immune Defic Syndr. 2013;64(2):197-203.

36. Helleberg M, Engsig FN, Kronborg G, Laursen AL, Pedersen G, Larsen $\mathrm{O}$, et al. Late presenters, repeated testing, and missed opportunities in a Danish nationwide HIV cohort. Scand J Infect Dis. 2012;44(4):282-8.

37. Jeong SJ, Italiano C, Chaiwarith R, Ng OT, Vanar S, Jiamsakul A, et al. Late presentation into care of HIV disease and its associated factors in Asia: results of TAHOD. AIDS Res Hum Retroviruses. 2016;32(3):25561.

38. Agaba PA, Meloni ST, Sule HM, Agbaji OO, Ekeh PN, Job GC, et al. Patients who present late to HIV care and associated risk factors in Nigeria. HIV Med. 2014;15(7):396-405.

Received June 4, 2018 Accepted in revised form June 30, 2019 